\title{
An Analysis of Macroeconomic Factors Affecting Foreign Exchange Rate
}

\author{
Thilak Venkatesan ${ }^{1 *}$ and M.S. Ponnamma ${ }^{2}$ \\ ${ }^{1}$ Assistant Professor, Presidency College, Bangalore, India \\ ${ }^{2}$ Student, Presidency College, Bangalore, India
}

\begin{abstract}
The Indian Rupee is launching its foot print in global market, which can be characterized by the fact that Bhutan and Nepal peg their currencies to Indian Rupee. The Indian economy contributes a higher GDP growth compared to other emerging economies. The increase in the GDP, aids well for a strong foreign exchange along with other economic factors such as gross domestic savings, forex reserve, inflation and so on. The various initiatives taken by the government recently to attract more foreign capital through various investment schemes and reduce interest rate as well assists to achieve a stabilized exchange rate in India. The RBI is focused for capital account convertibility, with various measures to achieve a freely floating currency from the present managed float in India. In view of recent appreciation of Chinese Yuan, it became tough for policy makers to take up an immediate action in supporting the home-grown industries. In this context, the research focuses to find and evaluate the various macroeconomic factors affecting the exchange rate and to model the factors using Auto Regressive Distributive Lag, to enable to forecast the exchange rate. The research focuses on finding the significant factors influencing the volatility of the exchange rate.
\end{abstract}

Keywords: Macroeconomic variables, Econometric modeling, ADF test, Vector Auto Regressive model, $A R D L$

JEL classification: B22, E44, E47, F31, G15, O11

\section{Introduction}

The Indian rupee is predominantly depended on the market forces and the RBI trades actively in the currency market to sustain and maintain low volatility in managing the exchange rate. When rupee appreciates, it makes imports cheaper and exports expensive. The importers would pay less for the goods which increases their profit margin. Similarly, the depreciation of the INR makes exports cheaper and imports expensive. The depreciation makes Indian goods and services cheaper which increases demand and generates higher revenue.
The advent of the floating exchange rate regime since the early 1970s has heightened the interest of MNCs in developing techniques and strategies for foreign exchange exposure management. The phenomenon of exchange rate movements is an important issue in international finance, the managers of multinational firm, international investors, the importers, and the exporters. There are several macroeconomic factors which affect the exchange rate. The factors that influence the exchange rate are inflation rate, forex reserve, GDP, money supply, oil price, IIP, bank rate, current account deficit, FII, FDI, WPI, exports, imports etc. The purpose of this study is to include all macro-economic

*Email: v.thilak@gmail.com 
indicators, to identify the factors that affect the rupee value and to model the factors affecting significantly to enable in controlling the Forex rate.

The secondary data used for the analysis was obtained from RBI Bulletin, only the data with matching time periods were used for analysis. The data was checked for stationarity, the indicators considered were stationary at first difference. The procedure subsequently was followed with VAR, residual diagnostics and ARDL.

\section{Review of Literature}

Review of literature examined few studies in the area of movement of foreign exchange rates.

Twarowska K. et al; (2000), analyzed the major determinants of exchange rate of Poland against the Euro. They observed that current account deficit and inflation rate is the most significant factors influencing the exchange rate. Interest rate in the economy and the government deficit were also found significant in influencing the exchange rate.

Boykorayev, B. (2008), studied the determinants of long run inflation and long run real exchange rate the effect of these over the nominal exchange rate. He observed that the significance of the model changed as the targeted countries changed.

DeeptiGulati et al; (2012), analysed the relationship between foreign exchange rate and the stock market indices namely the Sensex and the Nifty. They observed no causal relationship between the stock indices and the foreign exchange rate during the study period of 8 years viz., 2004 to 2012. However they summarised a low positive correlation between the stock indices and the foreign exchange rate.

Yaminikarmarkar et al., (2012) studied the effect of exchange rate volatility on the Sensex. The increase in the volatility of exchange rates exerted a significant negative effect on Sensex in the long run. They detected multicollinearity among the three variables i.e. foreign exchange reserves, Sensex, and RBI open market operations (net). They found a bi-directional causality among the two variables i.e., Sensex and foreign exchange reserves.

Mirchandani, A. (2013), analysed various macroeconomic variables that leads to the variation of the foreign exchange rate. The various factors included inflation; interest rate, current account deficit and the variation of these factors were observed to correlate with the variation in foreign exchange rate.

Raju, J. V. R., et al; (2014), analysed the correlation of exchange rate, inflation and interest rate. They observed that inflation and interest rate had a short term relationship where as they did not observe any long run influence on the exchange rate.

Ramasamy, R., et al; (2015), observed relationship of exchange rates of three different countries with their macroeconomic variables using bootstrapping technique. They identified that psychological factors like investor confidence dominated economic variables in influencing the exchange rates.

Khera, K., et al; (2015), observed the effect of various macroeconomic factors influencing the exchange rate post globalization. The study suggested to condense imports and to promote FDI to improve the exchange rate.

Wan Mohd Yaseer Mohd Abdoh, et al., (2016), compared the relationship of exports, interest rate and inflation on exchange rate of select ASEAN countries. They observed that exports had a significant role on the exchange rate movement.

Vidyavathi, B., et al; (2016), evaluated the leading macroeconomic indicators that influenced the exchange rate. They observed negative relationship GDP and exchange rate, inflation \& exchange rate, interest rate and exchange rate, external debt and exchange rate, and a weak positive relationship between FDI and Exchange rate.

The various studies observed limited number of factors and evolved to focus more on inter relationship of factors based of theories. Thus, the research focusses to 
include various factors based on literature, to include all factors to find the most significant among them.

\section{Statement of Problem}

The Indian economy faces higher volatility influenced majorly by exogenous shocks. All international transactions are affected with respect to fluctuations in the foreign exchange rate. This has caused increased uncertainties in rupee depreciation against the foreign currency, which intern has an adverse impact on Indian economy. The depreciation of the exchange rate has a higher impact with respect to the Indian economy as we become more dependent on imports vis-à-vis the exports. The exchange rate is the most crucial indicator of a country's strength or weakness. Thus, it becomes pertinent to understand the factors that influence the exchange rate and take apposite measures to contain them.

\subsection{Objectives}

- To explore the macroeconomic factors affecting the major exchange rate Vs the Rupee.

- To examine the relationship between the exchange rate and macro-economic variables.

- To develop a model to predict and forecast foreign exchange rate.

\subsection{Methodology}

The data for the research was collected through secondary sources. The sample used studying was for the period of 15years from 2000 to 2015.

\subsubsection{Augmented Dickey Fuller Test-Unit Root}

A series is said to be (weakly or covariance) stationary if the mean and auto-covariance's of the series do not depend on time. Any series that is not stationary is said to be no stationary. ADF test can be specified with no drift and no trend; with trend and no drift; lastly with both trend and drift as follows.

$\Delta \mathrm{Yt}=\delta \mathrm{Yt}-1+\sum \alpha \mathrm{i} \Delta \mathrm{Yt}-1+\mathrm{Ut}$ No drift, no intercept

$\Delta \mathrm{Yt}=\beta 0+\delta \mathrm{Yt}-1+\sum \alpha \mathrm{i} \Delta \mathrm{Yt}-1+\mathrm{Ut}$ Intercept, no drift term
$\Delta \mathrm{Yt}=\beta 0+\beta 1 \mathrm{t}+\delta \mathrm{Yt}-1+\sum \alpha \mathrm{i} \Delta \mathrm{Yt}-1+\mathrm{Ut}$ With intercept and trend

Furthermore, Phillips-perron unit root tests are used to reinforce the ADF. One advantage that the PhillipsPerron (PP) test has over the ADF test is that it is robust with respect to unspecified autocorrelation and heteroscedasticity in the disturbance process of the test regression, Brooks (2000). Therefore the PP test works well with financial time series. The two tests specify the Null hypothesis (H0) as that the time series has unit root, thus the time series is non-stationary against the Alternative Hypothesis (H1) that the time series has no unit root, thus a stationary time series:

H0: Time series has a unit $\operatorname{root}(\delta=1)$

H1: Time series has no unit root $(\delta \neq 1)$

\subsubsection{Vector Auto Regression}

Vector Auto Regression is an economic model used to capture the linear interdependencies among multiple times series of data. Vector auto regression is used to interpret the univariate autoregressive model by allowing for more than one evolving variable. Vector auto regression calculated with estimates in this project gives an equation which is used in solving ARDL model. The structural approach to simultaneous equations modeling uses economic theory to describe the relationships between several variables of interest.

\subsubsection{Histogram - Normality Test}

An informal approach to testing normality is of compare a histogram of the sample data to a normal probability curve. The empirical distribution of histogram data should be resembled normally distributed. It's difficult to analyze the distribution if the sample is small. In regressing the data for smaller sample one might proceed against the qualities of normal distribution with the same mean.

\subsubsection{Breusch-Godfrey Serial Correlation}

The Breusch-Godfrey serial correlation LM test is a autocorrelation in the errors in the regression model. It makes use of the residuals from the model being considered in a regression analysis, and the test statistic 
is derived from the above test. The test also specifies about the null hypothesis that there is no serial correlation of any order up to the $\mathrm{p}$ value.

\subsubsection{Breusch-Pagan-Godfrey Heteroskedasticity}

Breusch-Pagan-Godfrey test was developed in the year 1979 which is used for heteroskedasticity for a linear regression model. It tests whether the estimated variance of the residuals from a regression are dependent on the values of the independent variables. In that case it means it has heteroskedasticity. In other words heteroskedasticity means that the variables are scattered and doesn't have a linearity which is not favorable for the analysis.

\subsubsection{Stability Test (Cusum test)}

The CUSUM test (Brown, Durbin, \& Evans, 1975) is based on the cumulative sum of the recursive residuals. This option plots the cumulative sum together with the $5 \%$ critical lines. The test finds parameter instability if the cumulative sum goes outside the area between the two critical lines.

\subsubsection{Var Granger Causality/Block Exogeneity Wald Tests}

The Granger causality test is a statistical hypothesis test for determining whether one time series is useful in forecasting another. Granger causality is a statistical concept of causality that is based on prediction. According to Granger causality, if a signal X1 "Grangercauses" (or "G-causes") a signal X2, then past values of X1 should contain information that helps predict X2 above and beyond the information contained in past values of X2 alone.

\subsubsection{Auto Regressive Distributive Lag Model}

The test is used for finding out the long term relationship among the variables and finding out the significant determinants of the exchange rate.

\section{Data Analysis and Interpretations}

The data collected from 2000 to 2015 was found stationarity at different levels in unit root testing. The test was performed using $\mathrm{ADF}$ test.
Table 1.

\begin{tabular}{|c|c|c|}
\hline Foreign exchange rates & $\begin{array}{l}\text { Unit root testing- } \\
\text { stationarity }\end{array}$ & Probability \\
\hline US Dollar & $1^{\text {st }}$ difference & 0,006 \\
\hline Pound Sterling & $1^{\text {st }}$ difference & 0.0092 \\
\hline Euro & Level & 0.0076 \\
\hline Japanese Yen & $1^{15 t}$ difference & 0.0093 \\
\hline $\begin{array}{l}\text { Macroeconomic factors } \\
\text { Inflation }\end{array}$ & $\begin{array}{l}\text { Unit root testing- } \\
\text { stationarity } \\
1^{\text {st difference }}\end{array}$ & $\begin{array}{c}\text { Probability } \\
0.0279\end{array}$ \\
\hline $\begin{array}{l}\text { Foreign exchange } \\
\text { Reserve }\end{array}$ & $2^{\text {nd difference }}$ & 0.0029 \\
\hline GDP & Level & 0.0109 \\
\hline Money supply & $2^{\text {nd d }}$ difference & 0.0275 \\
\hline 0il price & $1^{15 t}$ difference & \\
\hline IIP & Level & 0.0245 \\
\hline Interest rate & $1^{\text {st }}$ difference & 0.0066 \\
\hline Current Account deficit & $1^{\text {st }}$ difference & 0.0333 \\
\hline Fll & Level & 0.0019 \\
\hline FDI & $1^{\text {st }}$ difference & 0.0032 \\
\hline WPI & $2^{\text {nd difference }}$ & 0.0211 \\
\hline Exports & Level & 0.036 \\
\hline Imports & Level & 0.0071 \\
\hline Gross Domestic Savings & $1^{\text {st }}$ difference & 0.0005 \\
\hline
\end{tabular}

A time series data is stationary when the probability is below 5\% level of significance. Most of the factors including dependent variable are found to be stationary at different levels. The USD, Pound and Yen were found stationary at first differences as a dependent variable but Euro was found stationary at level. Among 14 macroeconomic variables, some were stationary at level like GDP, IIP, FII, exports and imports. Some were stationary at first difference such as inflation rate, oil price, interest rate, CAD, FDI, GDS and some at second difference such as forex reserve, money supply and WPI.

From the above output of the ARDL Model, the probability of the $C(6)$ is less than 0.05 , which infers that Foreign Direct Investment is more significant factor in affecting the exchange rate Pound vs Rupee. From this we can observe that the $\mathrm{R}$ square is $73.01 \%$ which is a good sign for the model. 
Table 2. Vector auto regression estimates

Date: 05/03/16 Time: 09:51

Sample (adjusted): 20022014

Included observations: 13 after adjustments

Standard errors in ( ) \& t-statistics in []

\begin{tabular}{|c|c|c|c|c|c|c|c|}
\hline & DPOUND & DINFL & DOIL & DINTR & DCAD & DFDI & DGDS \\
\hline \multirow[t]{3}{*}{ DPOUND(-1) } & -0.282513 & -0.000214 & 0.602831 & -0.000432 & 67.90416 & -1289.904 & 94.88325 \\
\hline & (0.28386) & $(0.00052)$ & $(0.90257)$ & (0.00029) & (36.3405) & (923.216) & (94.1097) \\
\hline & {$[-0.99525]$} & {$[-0.41242]$} & [ 0.66791] & {$[-1.47637]$} & [ 1.86856$]$ & {$[-1.39718]$} & [ 1.00822] \\
\hline \multirow[t]{3}{*}{ DINFL(-1) } & -296.7579 & 0.500739 & 130.7677 & -0.281882 & 37407.32 & 709977.4 & 47011.45 \\
\hline & (200.977) & $(0.36690)$ & (639.028) & $(0.20724)$ & (25729.5) & (653647.) & (66630.7) \\
\hline & {$[-1.47658]$} & [ 1.36478] & [ 0.20464$]$ & {$[-1.36020]$} & [ 1.45387$]$ & [ 1.08618$]$ & [ 0.70555$]$ \\
\hline \multirow[t]{3}{*}{ DOIL(-1) } & -0.105930 & $8.57 \mathrm{E}-05$ & -1.122213 & 0.000475 & 19.34229 & 1011.808 & -43.32605 \\
\hline & (0.13958) & $(0.00025)$ & $(0.44379)$ & $(0.00014)$ & (17.8687) & (453.947) & (46.2739) \\
\hline & {$[-0.75894]$} & [ 0.33637] & [-2.52868] & [ 3.30005$]$ & [ 1.08247] & [ 2.22891] & {$[-0.93630]$} \\
\hline \multirow[t]{3}{*}{$\operatorname{DINTR}(-1)$} & 127.9136 & -0.644332 & 41.41485 & 0.269139 & -15326.12 & 1228443. & 28107.57 \\
\hline & (114.443) & $(0.20893)$ & (363.885) & $(0.11801)$ & (14651.2) & (372209.) & (37941.8) \\
\hline & [ 1.11770] & {$[-3.08402]$} & [ 0.11381] & [ 2.28069] & {$[-1.04606]$} & [ 3.30041$]$ & [ 0.74081$]$ \\
\hline \multirow[t]{3}{*}{ DCAD $(-1)$} & 0.000437 & $-1.84 \mathrm{E}-05$ & -0.009700 & $1.88 \mathrm{E}-06$ & -0.489633 & 12.07689 & 2.283120 \\
\hline & $(0.00244)$ & $(4.5 \mathrm{E}-06)$ & $(0.00776)$ & $(2.5 \mathrm{E}-06)$ & $(0.31235)$ & (7.93512) & (0.80888) \\
\hline & [ 0.17926] & {$[-4.12172]$} & {$[-1.25032]$} & [ 0.74853$]$ & [-1.56758] & [ 1.52195$]$ & [ 2.82257] \\
\hline \multirow[t]{3}{*}{ DFDI(-1) } & -0.000187 & $2.75 \mathrm{E}-07$ & -0.000202 & $-2.33 \mathrm{E}-07$ & -0.011801 & -0.379152 & 0.011180 \\
\hline & $(6.9 \mathrm{E}-05)$ & $(1.3 \mathrm{E}-07)$ & $(0.00022)$ & (7.1E-08) & $(0.00880)$ & $(0.22357)$ & $(0.02279)$ \\
\hline & {$[-2.71346]$} & [ 2.19277] & {$[-0.92299]$} & {$[-3.28305]$} & [-1.34091] & [-1.69588] & [ 0.49054] \\
\hline \multirow[t]{3}{*}{ DGDS(-1) } & -0.000989 & $-8.34 \mathrm{E}-06$ & 0.012924 & 7.07E-06 & -1.028473 & -9.631986 & 0.525501 \\
\hline & $(0.00293)$ & $(5.3 \mathrm{E}-06)$ & $(0.00931)$ & $(3.0 \mathrm{E}-06)$ & $(0.37493)$ & (9.52496) & (0.97094) \\
\hline & {$[-0.33756]$} & {$[-1.55942]$} & [ 1.38790] & [ 2.34127] & {$[-2.74311]$} & [-1.01124] & [ 0.54123] \\
\hline \multirow[t]{3}{*}{ C } & 8.124331 & 0.001608 & -5.034120 & -0.003344 & 425.5647 & 22684.33 & 1298.038 \\
\hline & (2.91857) & $(0.00533)$ & $(9.27990)$ & $(0.00301)$ & (373.640) & (9492.20) & (967.604) \\
\hline & [ 2.78367] & [ 0.30176$]$ & {$[-0.54248]$} & {$[-1.11122]$} & [ 1.13897$]$ & [ 2.38979] & [ 1.34150$]$ \\
\hline R-squared & 0.729749 & 0.864215 & 0.745435 & 0.943852 & 0.760026 & 0.833375 & 0.825382 \\
\hline Adj. R-squared & 0.351397 & 0.674116 & 0.389044 & 0.865244 & 0.424063 & 0.600099 & 0.580916 \\
\hline Sum sq. resids & 198.2444 & 0.000661 & 2004.235 & 0.000211 & 3249148. & $2.10 \mathrm{E}+09$ & 21789986 \\
\hline S.E. equation & 6.296736 & 0.011495 & 20.02116 & 0.006493 & 806.1201 & 20479.19 & 2087.582 \\
\hline F-statistic & 1.928758 & 4.546135 & 2.091619 & 12.00709 & 2.262230 & 3.572492 & 3.376265 \\
\hline Log likelihood & -36.15578 & 45.82032 & -51.19365 & 53.24634 & -99.23440 & -141.2885 & -111.6043 \\
\hline Akaike AIC & 6.793198 & -5.818510 & 9.106715 & -6.960975 & 16.49760 & 22.96746 & 18.40066 \\
\hline Schwarz SC & 7.140859 & -5.470849 & 9.454376 & -6.613314 & 16.84526 & 23.31513 & 18.74832 \\
\hline Mean dependent & 2.206138 & 0.002000 & 2.571538 & 0.000623 & -137.9817 & 13111.77 & 1839.305 \\
\hline S.D. dependent & 7.818547 & 0.020137 & 25.61440 & 0.017687 & 1062.214 & 32384.46 & 3224.726 \\
\hline \multicolumn{3}{|c|}{ Determinant resid covariance (dof adj.) } & \multicolumn{2}{|c|}{0.000000} & & & \\
\hline \multicolumn{3}{|c|}{ Determinant resid covariance } & \multicolumn{2}{|c|}{0.000000} & & & \\
\hline
\end{tabular}


Table 3. ARDL model

Dependent Variable: DPOUND

Method: Least Squares

Date: 05/03/16 Time: 09:54

Sample (adjusted): 20022015

Included observations: 14 after adjustments

DPOUND $=\mathrm{C}(1)^{*}$ DPOUND $(-1)+\mathrm{C}(2)^{*} \operatorname{DINFL}(-1)+\mathrm{C}(3)^{*} \mathrm{DOIL}(-1)+\mathrm{C}(4)$

${ }^{*} \operatorname{DINTR}(-1)+\mathrm{C}(5)^{*} \mathrm{DCAD}(-1)+\mathrm{C}(6)^{*} \mathrm{DFDI}(-1)+\mathrm{C}(7)^{*} \operatorname{DGDS}(-1)+\mathrm{C}(8)$

\begin{tabular}{ccccc} 
& Coefficient & Std. Error & t-Statistic & Prob. \\
\hline $\mathrm{C}(1)$ & -0.266841 & 0.245991 & -1.084759 & 0.3197 \\
$\mathrm{C}(2)$ & -272.6833 & 131.4116 & -2.075031 & 0.0833 \\
$\mathrm{C}(3)$ & -0.086690 & 0.075731 & -1.144715 & 0.2959 \\
$\mathrm{C}(4)$ & 127.0467 & 104.6747 & 1.213728 & 0.2705 \\
$\mathrm{C}(5)$ & 0.000189 & 0.001796 & 0.105323 & 0.9196 \\
$\mathrm{C}(6)$ & -0.000184 & $6.16 \mathrm{E}-05$ & -2.989125 & 0.0243 \\
$\mathrm{C}(7)$ & -0.001470 & 0.000753 & -1.950371 & 0.0990 \\
$\mathrm{C}(8)$ & 8.243314 & 2.595142 & 3.176441 & 0.0192 \\
R-squared & 0.730199 & Mean dependent var & 2.031871 \\
$\begin{array}{c}\text { Adjusted } \\
\text { R-squared }\end{array}$ & 0.415430 & S.D. dependent var & 7.540064 \\
$\begin{array}{c}\text { S.E. of } \\
\text { regression }\end{array}$ & 5.764917 & Akaike info criterion & 6.637018 \\
$\begin{array}{c}\text { Sum squared } \\
\text { resid }\end{array}$ & 199.4056 & Schwarz criterion & 7.002194 \\
$\begin{array}{c}\text { Log } \\
\text { likelihood }\end{array}$ & -38.45913 & Hannan-Quinn criter. & 6.603214 \\
$\begin{array}{c}\text { F-statistic } \\
\begin{array}{c}\text { Prob } \\
\text { (F-statistic) }\end{array}\end{array}$ & 2.319798 & Durbin-Watson stat & 1.876254 \\
\hline & 0.162430 & & \\
\hline
\end{tabular}

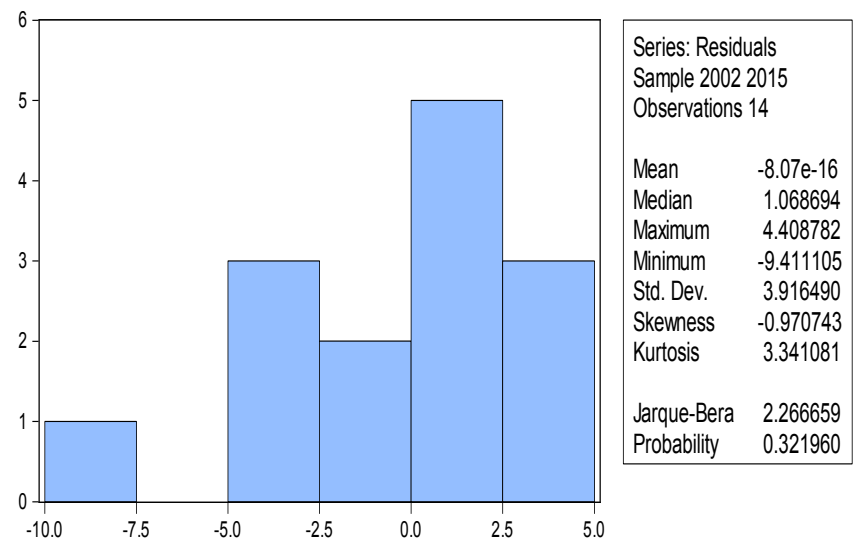

Figure 1. Histogram andnormalitytest

The other factors significant at $10 \mathrm{C} \%$ significance level are Inflation and Gross Domestic Savings.
Using the above ARDL model, residual diagnostic was performed for Auto correlation and normality. let's check if the data taken for analysis is normally distributed or not.

Jarque-Bera statistic was used to check for the Normality of the residuals, the probability was more than 0.05 that is 0.3219 or $32.19 \%$, thus the data was normally distributed. The model was further checked for serial correlation. A good model should not have serial correlation. The serial correlation test was done using LM test.

Table 4. Breusch-godfrey serial correlation LM test

\begin{tabular}{|c|c|c|c|c|}
\hline F-statistic & 0.025380 & \multicolumn{2}{|c|}{ Prob. $F(1,5)$} & 0.8797 \\
\hline Obs*R-squared & 0.070705 & \multicolumn{2}{|c|}{ Prob. Chi-Square(1) } & 0.7903 \\
\hline \multicolumn{5}{|l|}{ Test Equation: } \\
\hline \multicolumn{5}{|c|}{ Dependent Variable: RESID } \\
\hline \multicolumn{5}{|c|}{ Method: Least Squares } \\
\hline \multicolumn{5}{|c|}{ Date: 05/03/16 Time: 09:56 } \\
\hline \multicolumn{5}{|c|}{ Sample: 20022015} \\
\hline \multicolumn{5}{|c|}{ Included observations: 14} \\
\hline \multicolumn{5}{|c|}{ Presample missing value lagged residuals set to zero. } \\
\hline Variable & Coefficient & Std. Error & t-Statistic & Prob. \\
\hline$C(1)$ & -0.038798 & 0.362710 & -0.106968 & 0.9190 \\
\hline $\mathrm{C}(2)$ & -2.985548 & 144.8080 & -0.020617 & 0.9843 \\
\hline $\mathrm{C}(3)$ & 0.004409 & 0.087255 & 0.050534 & 0.9617 \\
\hline $\mathrm{C}(4)$ & -4.251494 & 117.4476 & -0.036199 & 0.9725 \\
\hline $\mathrm{C}(5)$ & $8.31 \mathrm{E}-05$ & 0.002031 & 0.040912 & 0.9689 \\
\hline $\mathrm{C}(6)$ & $5.36 \mathrm{E}-06$ & $7.52 \mathrm{E}-05$ & 0.071208 & 0.9460 \\
\hline $\mathrm{C}(7)$ & $-4.86 \mathrm{E}-05$ & 0.000878 & -0.055380 & 0.9580 \\
\hline$C(8)$ & 0.097501 & 2.900941 & 0.033610 & 0.9745 \\
\hline RESID(-1) & 0.106191 & 0.666568 & 0.159311 & 0.8797 \\
\hline R-squared & 0.005050 & \multicolumn{2}{|c|}{ Mean dependent var } & $-8.07 E-16$ \\
\hline $\begin{array}{l}\text { Adjusted } \\
\text { R-squared }\end{array}$ & -1.586869 & \multicolumn{2}{|c|}{ S.D. dependent var } & 3.916490 \\
\hline $\begin{array}{l}\text { S.E. of } \\
\text { regression }\end{array}$ & 6.299184 & \multicolumn{2}{|c|}{ Akaike info criterion } & 6.774812 \\
\hline $\begin{array}{l}\text { Sum squared } \\
\text { resid }\end{array}$ & 198.3986 & \multicolumn{2}{|c|}{ Schwarz criterion } & 7.185635 \\
\hline Log likelihood & -38.42368 & \multicolumn{2}{|c|}{ Hannan-Quinn criter. } & 6.736783 \\
\hline F-statistic & 0.003172 & \multicolumn{2}{|c|}{ Durbin-Watson stat } & 1.986638 \\
\hline Prob(F-statistic) & 1.000000 & & & \\
\hline
\end{tabular}


The result of the serial correlation, was found to have a probability of the chi square more than 0.05 or $5 \%$ which is 0.7903 or $79.03 \%$ and hence signifying to accept the Null of no serial correlation. The residuals are further tested for heteroscedasticity.

The probability of the chi square relating the observed $\mathrm{R}$ square was more than 0.05 or $5 \%$ that is 0.9185 or $91.85 \%$ thus the model proves there is no heteroscedasticity. The model satisfies all the residual diagnostic checks hence proceeded with the stability test. The stability test is estimated with help of recursive estimates using Cusum test. The graph of the stability is below:

Table 5. Test for Heteroscedasticity

Heteroscedasticity Test: Breusch-Pagan-Godfrey

\begin{tabular}{|c|c|c|c|c|}
\hline F-statistic & 0.196482 & \multicolumn{2}{|c|}{ Prob. $F(7,6)$} & 0.9746 \\
\hline Obs*R-squared & 2.610750 & \multicolumn{2}{|c|}{ Prob. Chi-Square(7) } & 0.9185 \\
\hline $\begin{array}{c}\text { Scaled } \\
\text { explained SS }\end{array}$ & 0.561304 & \multicolumn{2}{|c|}{ Prob. Chi-Square(7) } & 0.9992 \\
\hline \multicolumn{5}{|l|}{ Test Equation: } \\
\hline \multicolumn{5}{|c|}{ Dependent Variable: RESID $\odot$} \\
\hline \multicolumn{5}{|c|}{ Method: Least Squares } \\
\hline \multicolumn{5}{|c|}{ Date: 05/03/16 Time: 09:57 } \\
\hline \multicolumn{5}{|c|}{ Sample: 20022015} \\
\hline \multicolumn{5}{|c|}{ Included observations: 14} \\
\hline Variable & Coefficient & Std. Error & t-Statistic & Prob. \\
\hline C & 8.948363 & 13.51629 & 0.662043 & 0.5325 \\
\hline DPOUND(-1) & 0.442857 & 1.281194 & 0.345659 & 0.7414 \\
\hline DINFL(-1) & 122.5895 & 684.4320 & 0.179111 & 0.8637 \\
\hline DOIL(-1) & 0.275537 & 0.394428 & 0.698574 & 0.5110 \\
\hline DINTR(-1) & 73.48498 & 545.1780 & 0.134791 & 0.8972 \\
\hline $\operatorname{DCAD}(-1)$ & -0.007394 & 0.009356 & -0.790292 & 0.4594 \\
\hline $\mathrm{DFDI}(-1)$ & $8.21 \mathrm{E}-05$ & 0.000321 & 0.256052 & 0.8065 \\
\hline $\operatorname{DGDS}(-1)$ & 0.001072 & 0.003924 & 0.273134 & 0.7939 \\
\hline R-squared & 0.186482 & \multicolumn{2}{|c|}{ Mean dependent var } & 14.24326 \\
\hline $\begin{array}{l}\text { Adjusted } \\
\text { R-squared }\end{array}$ & -0.762622 & \multicolumn{2}{|c|}{ S.D. dependent var } & 22.61570 \\
\hline $\begin{array}{l}\text { S.E. of } \\
\text { regression }\end{array}$ & 30.02545 & \multicolumn{2}{|c|}{ Akaike info criterion } & 9.937527 \\
\hline $\begin{array}{l}\text { Sum squared } \\
\text { resid }\end{array}$ & 5409.167 & \multicolumn{2}{|c|}{ Schwarz criterion } & 10.30270 \\
\hline Log likelihood & -61.56269 & \multicolumn{2}{|c|}{ Hannan-Quinn criter. } & 9.903724 \\
\hline F-statistic & 0.196482 & \multicolumn{2}{|c|}{ Durbin-Watson stat } & 1.801387 \\
\hline $\operatorname{Prob}(\mathrm{F}-$ statistic) & 0.974630 & & & \\
\hline
\end{tabular}

http://www.informaticsjournals.com/index.php/sdmimd | Vol 8 | Issue 1 | March 2017

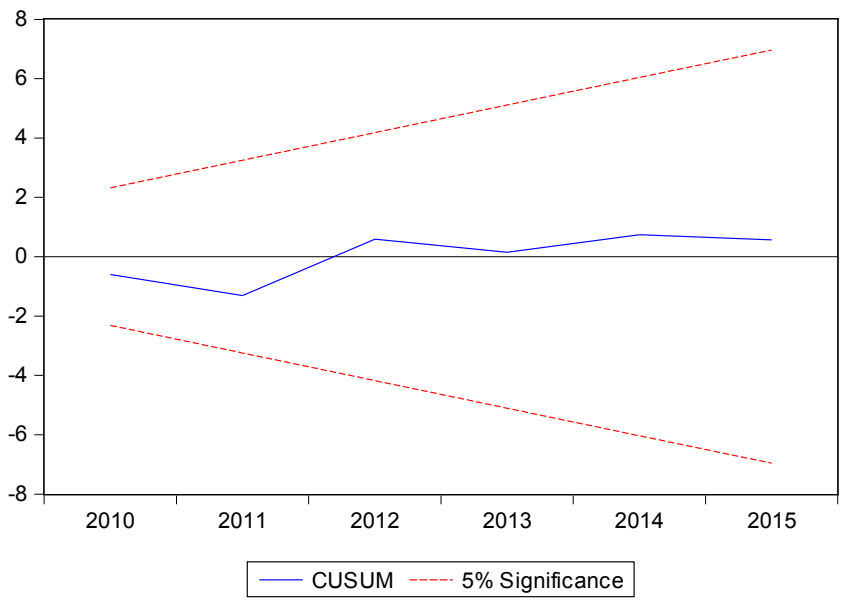

Figure 2. Stability Test- CUSUM Test

Table 6. VAR Granger causality/block exogeneity wald tests

Date: 05/03/16 Time: 09:58

Sample: 20002015

Included observations: 13

Dependent variable: DPOUND

\begin{tabular}{cccc}
\hline Excluded & Chi-sq & Df & Prob. \\
\hline DINFL & 2.180278 & 1 & 0.1398 \\
DOIL & 0.575996 & 1 & 0.4479 \\
DINTR & 1.249262 & 1 & 0.2637 \\
DCAD & 0.032134 & 1 & 0.8577 \\
DFDI & 7.362855 & 1 & 0.0067 \\
DGDS & 0.113947 & 1 & 0.7357 \\
All & 12.90676 & 6 & 0.0445 \\
\hline
\end{tabular}

From the above graph, the blue line signifies the data, which was within the $5 \%$ significance level. This infers that the data used in the model using ARDL was stable. Further using the Granger causality test, the unidirectional and bidirectional influences of the exchange rate was observed.

From the above table, the factor influencing the Pound proves that FDI affects Pound exchange rate significantly followed by Inflation. The above is the exogeneity test of Granger causality, the estimation of influence and analysis was done using granger causality test pairwise test.

The following inferences was made based on the pairwise Granger causality test,

a. The inflation influences the pound exchange rate unidirectionally. 
Table 7. Pairwise Granger causality tests

Date: 05/03/16 Time: $14: 58$

Sample: 20002015

Lags: 2

\begin{tabular}{|c|c|c|c|}
\hline Null Hypothesis: & Obs & F-Statistic & Prob. \\
\hline DINFL does not Granger Cause DPOUND & 13 & 0.64381 & 0.5505 \\
\hline DPOUND does not Granger Cause DINFL & & 6.29574 & 0.0228 \\
\hline DOIL does not Granger Cause DPOUND & 13 & 1.06017 & 0.3905 \\
\hline DPOUND does not Granger Cause DOIL & & 2.36852 & 0.1556 \\
\hline DINTR does not Granger Cause DPOUND & 13 & 1.05759 & 0.3913 \\
\hline DPOUND does not Granger Cause DINTR & & 0.17040 & 0.8463 \\
\hline DCAD does not Granger Cause DPOUND & 13 & 1.49562 & 0.2807 \\
\hline DPOUND does not Granger Cause DCAD & & 2.21547 & 0.1715 \\
\hline DFDI does not Granger Cause DPOUND & 13 & 0.70306 & 0.5233 \\
\hline DPOUND does not Granger Cause DFDI & & 1.90017 & 0.2112 \\
\hline DGDS does not Granger Cause DPOUND & 12 & 2.60032 & 0.1431 \\
\hline DPOUND does not Granger Cause DGDS & & 0.08651 & 0.9181 \\
\hline DOIL does not Granger Cause DINFL & 13 & 0.04256 & 0.9585 \\
\hline DINFL does not Granger Cause DOIL & & 0.79652 & 0.4837 \\
\hline DINTR does not Granger Cause DINFL & 13 & 1.07942 & 0.3846 \\
\hline DINFL does not Granger Cause DINTR & & 0.27322 & 0.7678 \\
\hline DCAD does not Granger Cause DINFL & 13 & 5.46916 & 0.0318 \\
\hline DINFL does not Granger Cause DCAD & & 12.6380 & 0.0033 \\
\hline DFDI does not Granger Cause DINFL & 13 & 7.53767 & 0.0144 \\
\hline DINFL does not Granger Cause DFDI & & 0.28665 & 0.7582 \\
\hline DGDS does not Granger Cause DINFL & 12 & 0.08329 & 0.9210 \\
\hline DINFL does not Granger Cause DGDS & & 1.42642 & 0.3023 \\
\hline DINTR does not Granger Cause DOIL & 13 & 0.16348 & 0.8519 \\
\hline DOIL does not Granger Cause DINTR & & 6.13644 & 0.0242 \\
\hline DCAD does not Granger Cause DOIL & 13 & 1.95889 & 0.2030 \\
\hline DOIL does not Granger Cause DCAD & & 1.69841 & 0.2428 \\
\hline DFDI does not Granger Cause DOIL & 13 & 0.88421 & 0.4498 \\
\hline DOIL does not Granger Cause DFDI & & 1.66017 & 0.2494 \\
\hline DGDS does not Granger Cause DOIL & 12 & 2.23419 & 0.1777 \\
\hline DOIL does not Granger Cause DGDS & & 0.10839 & 0.8988 \\
\hline DCAD does not Granger Cause DINTR & 13 & 0.53394 & 0.6058 \\
\hline DINTR does not Granger Cause DCAD & & 0.94600 & 0.4278 \\
\hline DFDI does not Granger Cause DINTR & 13 & 2.79926 & 0.1198 \\
\hline DINTR does not Granger Cause DFDI & & 0.62254 & 0.5607 \\
\hline DGDS does not Granger Cause DINTR & 12 & 6.25770 & 0.0276 \\
\hline DINTR does not Granger Cause DGDS & & 1.91051 & 0.2177 \\
\hline DFDI does not Granger Cause DCAD & 13 & 3.16708 & 0.0970 \\
\hline DCAD does not Granger Cause DFDI & & 0.62082 & 0.5615 \\
\hline DGDS does not Granger Cause DCAD & 12 & 5.15528 & 0.0420 \\
\hline DCAD does not Granger Cause DGDS & & 10.5327 & 0.0077 \\
\hline DGDS does not Granger Cause DFDI & 12 & 0.52772 & 0.6117 \\
\hline DFDI does not Granger Cause DGDS & & 1.69684 & 0.2507 \\
\hline
\end{tabular}

b. Current account deficit (CAD) was found influencing inflation bi-directionally.

c. Inflation Granger causes FDI unidirectionally.

d. Interest rate Granger causes oil price unidirectionally.

e. Interest rate Granger causes gross domestic saving (GDS) unidirectionally and

f. GDS Granger causes CAD unidirectionally.

\section{Implications}

The ARDL model estimating the Pound with other factors found that FDI was more significant to the Pound compared to other factors which had a probability less than 0.05 . Inflation rate and GDS was found to be less significant with a probability less than 0.10 . This proved that FDI should be focused more so that the exchange rate can be stabilized. Estimating the Granger causality for model was found that FDI is the variable which has long term relationship with high significance compared to other factors. Overall significance of all factors had a strong impact on Pound exchange rate with less than 0.05 that is $4.45 \%$. From the Granger causality test, it was estimated that the inflation rate, CAD, FDI, interest rate, oil price and GDS had impact on each other which affects overall to the economy as well as exchange rate of the Rupee.

\section{Conclusion}

The study analyzed that FDI has a long-term relationship in affecting the fluctuations of the Indian rupee. This study used ARDL model for estimating the significance of macroeconomic factors towards the exchange rate. It can be concluded that overall exchange rate is affected from some variables which proved to be significant influencing the volatility. The short run affects however, are not straight forward, as they are likely to depend on specific characters of the economy. Inflation had a negative impact on foreign exchange rate and therefore higher the rate of inflation affects the exchange rate with respect to other countries negatively. Inflation affects FDI as per the analysis using Granger causality. 


\section{Limitations and Scope For Future Research}

The secondary data collected for analysis is limited to 15years from 2000 to 2015 . The data collected for the analysis is limited to few factors. The relationship of the factors as independent variables with exchange rate USD, Yen and Euro as dependent variable had shown that it was insignificant and thus the data was analyzed with POUND/INR as dependent variable. Few factors were limited due to their significance using ARDL. The analysis can provide considering structural break during 2008, which will provide much more insight of the influencing variables.

\section{References}

Apte P. G.. (2014). International Financial Management, Tata Mcgraw Hill Publishing Limited

Boykorayev, B. (2008). Factors that determine nominal exchangerates andempiricalevidence ofcross-sectional analysis, retrieved frompure.au.dk/portal-asb-student/ files/3262/Bahodir_Boykorayev._Master_thesis.pdf.

Deepti Gulati \& Monika Kakhani. (2012). Relationship Between Stock Market and Foreign Exchange Market in India: An Empirical Study. Pacific Business Revier International, retrieved from www.pbr.co.in/Vol-5\%20Iss5/7.pdf

Khera, K., \& Singh, I. (2015). Effect of macro economic factors on rupee value. Delhi Business Review, 16(1), 87-96.
Madhu, Vij. (2014). International Financial Management, Tata Mcgraw Hill Publishing Limited

Mirchandani, A. (2013). Analysis of Macroeconomic Determinants of Exchange Rate Volatility in India. International Journal of Economics and Financial Issues, 3(1), 172-179.

Mohd, W., Mohd, Y., Hafizha, N., Yusuf, M., Azreen, S., Zulkifli, M., Ibrahim, N. J. et al. (2016). Macroeconomic Factors That Influence Exchange Rate Fluctuation in ASEAN Countries. International Academic Research Journal of Social Science, 2(1), 89-94.

Raju, J. V. R. (2014). An Econometric analysis pertaining to exchange rate dynamics in India Retrived from $w w w$. sibm.edu/assets/pdf/samvad8/econometric.pdf

Ramasamy, R., \& Abar, S. K. (2015). Influence of Macroeconomic Variables on Exchange Rates.Journal of Economics, Business \& Management, 3(2), 276-281. Retrieved from https://doi.org/10.7763/JOEBM.2015. V3.194 https://doi.org/10.7763/JOEBM.2015.V3.194

Twarowska, K. (2000). Analysis of factors affectng fluctuations in the exchange rate of Polish Zloty against Euro, retrieved from www.toknowpress.net/ISBN/978-9616914-09-3/papers/ML14-652.pdf.

Vidyavathi, B., Keerti, K., \& Pooja, A. (2016). A Study on macro economic indicators and their impact on exchange rates. International Journal of Engineering and Management Studies, 7(3), 160-169.

Yamini Karmarkar, M. K. \& A. M. (2012). Exchange Rate and Macro-economic indicators: A Causal Study for India of the Past Decade. Pacific Business Review International, Retrieved from www. pbr.co.in/PDF\%20 Copy/9.pdf. 
